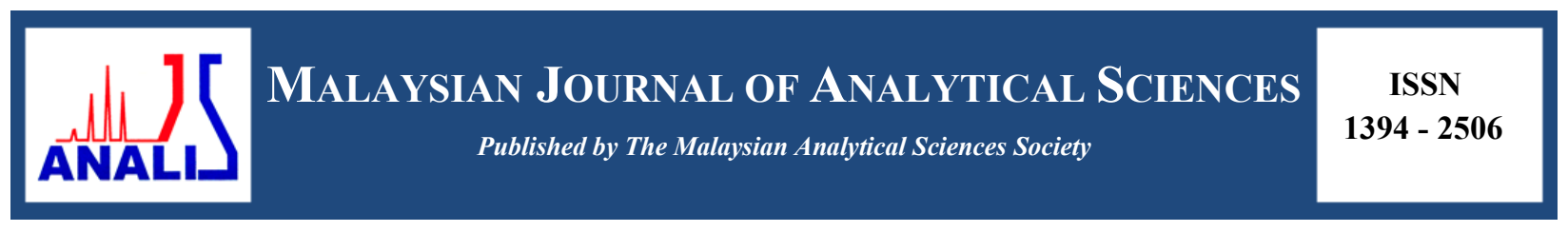

\title{
ISOLATION AND CHARACTERISATION OF MICROPLASTIC ABUNDANCE IN Lates calcarifer FROM SETIU WETLANDS, MALAYSIA
}

\author{
(Pemisahan dan Pencirian Plastik-Mikro di dalam Lates calcarifer dari Tanah Bencah Setiu, \\ Malaysia)
}

\author{
Yusof Shuaib Ibrahim*, Ruthra Rathnam, Sabiqah Tuan Anuar, Wan Mohd Afiq Wan Mohd Khalik \\ School of Marine and Environmental Sciences, \\ Universiti Malaysia Terengganu, 21030 Kuala Nerus, Terengganu, Malaysia \\ *Corresponding author: yusofshuaib@umt.edu.my
}

Received: 20 July 2017; Accepted: 14 September 2017

\begin{abstract}
The presence of microplastics $(<1 \mathrm{~mm})$ in wild and cage-cultured Asian sea bass (Lates calcarifer) was successfully studied. Fish samples were collected from Setiu Wetlands in October 2016. Microplastics were isolated from fish samples using the alkaline solution method (10 M of $\mathrm{NaOH}$ solution). Microplastics were sorted visually according to their shapes and colours after being observed under dissecting microscope. A total of 4,498 pieces of microplastics were identified and threadlike shape was the most abundant microplastic particles found during this study. The identification of functional groups in the composition of microplastics was achieved using Fourier transform infrared (FTIR) spectroscopy. Microplastics, with the presence of strong peaks at $v=3342 \mathrm{~cm}^{-1}(\mathrm{~N}-\mathrm{H} \mathrm{str}), 1510 \mathrm{~cm}^{-1}\left(\mathrm{~N}-\mathrm{H}\right.$ bend) and $v=1706 \mathrm{~cm}^{-1}(\mathrm{C}=\mathrm{O} \mathrm{str})$ are associated with the materials consist of polyamide. Additionally, peaks related to the polyvinyl alcohol groups are recorded at $v=3321-4323 \mathrm{~cm}^{-1}(\mathrm{O}-\mathrm{H} \mathrm{str}), 1706 \mathrm{~cm}^{-1}$ $\left(\mathrm{C}=\mathrm{O}\right.$ str), $1219 \mathrm{~cm}^{-1}$ (O-H wag) and $v=1028-1128 \mathrm{~cm}^{-1}$ (C-O str). The abundance levels of microplastics ingested by wild and cage-cultured fishes are statistically significantly different, $\mathrm{p}<0.05$.
\end{abstract}

Keywords: Asian sea bass, fish ingestion, microplastics, polymer, wetland environment

\section{Abstrak}

Kemunculan plastik-mikro $(<1 \mathrm{~mm})$ di dalam ikan siakap liar dan sangkar ternakan (Lates calcarifer) telah berjaya dikaji. Sampel ikan diambil dari tanah bencah Setiu semasa bulan Oktober 2016. Plastik-mikro telah diasingkan daripada sampel ikan mengunakan kaedah larutan beralkali (10 M larutan $\mathrm{NaOH})$. Plastik-mikro telah diasingkan secara visual dibawah mikroskop mengikut perbezaan warna dan bentuk. Sejumlah 4,498 pecahan plastik-mikro telah dikenalpasti dan bentuk benang merupakan partikel yang paling kerap dijumpai semasa kajian ini dijalankan. Pengenalpastian kumpulan berfungsi bagi komposisi plastikmikro telah dicapai menggunakan spektroskopi FTIR. Analisis plastik-mikro menunjukkan kehadiran puncak yang jelas pada $v=3342 \mathrm{~cm}^{-1}$ (N-H str), $1510 \mathrm{~cm}^{-1}\left(\mathrm{~N}-\mathrm{H}\right.$ bend) dan $v=1706 \mathrm{~cm}^{-1}(\mathrm{C}=\mathrm{O}$ str) bagi komposisi polimer kumpulan poliamida. Tambahan, puncak yang menunjukan kehadiran kumpulan polivinil alkohol dicatatkan pada $v=3321-4323 \mathrm{~cm}^{-1}$ (O-H str), $1706 \mathrm{~cm}^{-1}$ (C=O str), $1219 \mathrm{~cm}^{-1}$ (O-H wag) dan $v=1028-1128 \mathrm{~cm}^{-1}$ (C-O str). Aras kehadiran plastik-mikro yang dihadam oleh ikan liar dan sangkar ternakan adalah berbeza secara signifikan, $\mathrm{p}<0.05$.

Kata kunci: ikan siakap, penghadaman oleh ikan, plastik-mikro, polimer, persekitaran tanah bencah

\section{Introduction}

Microplastics are generally defined as plastics with size less than $1 \mathrm{~mm}$ in diameter [1], which makes much easier for them to be displaced into biota. Despite no possibility of danger regarding microplastics and marine organisms recorded at this stage, there is a great concern about the potential risks that microplastics may pose to organisms via 


\section{Yusof Shuaib et al: ISOLATION AND CHARACTERISATION OF MICROPLASTIC ABUNDANCE IN Lates calcarifer FROM SETIU WETLANDS, MALAYSIA}

ingestion, which is then transferred to food chain and ultimately poses risks to human health. Studies over the past decades have shown that microplastics are widespread in the marine environment including sea surface, shoreline or sea bed, and their abundance has increased annually.

Microplastics could have both physical and chemical effects on the organisms that ingest the pollutant. If ingested, microplastics may pass through the gut or retained in the digestive tract [2]. Fibres may knot or clump and it could be hazardous if the passage of food is blocked. The accumulation of debris in the digestive tract leads to the difficulty in breathing as some plastic particles could choke the organism. According to Ivar do Sul et al. [3], microplastics accumulation occurred through the food web, from the smallest organisms like plankton to the largest fish.

In fact, small-sized microplastics have a great potential to be ingested by a wide range of marine organisms including fish. A great variety of fish species across the world have been proven to ingest synthetic polymers. For instance, a total of $35 \%$ of five mesopelagic and one epipelagic fish species from the North Pacific were found to have ingested plastics with an average of 2.1 pieces of plastic per fish [4]. Meanwhile, three different species of bottom-feeding catfish were investigated in a Brazilian estuary and as a result, $17-33 \%$ of the sampled fishes had ingested plastics [5]. Lusher et al. [6] in their work found that ten fish species from the English Channel had ingested microplastics (both pelagic and demersal species), with a total of $37 \%$ of the sample studied was affected.

Foekema et al. [7] found that only $2.6 \%$ of the fish from the North Sea contained microplastics, but this was after excluding textile fibres from their data analysis. Of the seven-species investigated, five of the subjects studied contained plastics. Atlantic cod (Gadus morhua) was one of the species studied and the abundance levels varied depending on the location, in which $0-15 \%$ of the individuals contained microplastics. A recent study carried out by Rummel et al. [8] also found relatively low plastic content in fish (both pelagic and demersal species) from the North Sea and the Baltic Sea, where 5.5\% of all fishes were affected by this pollutant. To date, no study has cited the comparison of microplastic particles between two fishes derived from different habitat locations.

In Malaysia, the research exploration related to the issue of microplastics is still limited. To the best of our knowledge, there are several studies documenting the occurrence of microplastic in mangrove sediment [9], sandy beaches [10], and bivalves [11]. Indeed, there have been no studies documenting the ingestion of microplastics among estuarine fishes of Malaysia.

Lates calcarifer or commonly known as the Asian sea bass in Malaysia is a commercial fish found in great abundance along the estuary of Setiu Wetlands, Terengganu. They are found in both open environment and cagecultured by the local fishermen. This area has nine distinctive ecosystems namely beach, sea, mudflat, river, lagoon, estuary, island, coastal forest, and mangroves. Thus, Setiu Wetlands is the only wetland in Malaysia that can be found with a great diversity of ecosystems [12]. The presence of microplastic particles in the lower trophic level organisms such as bivalves has been proven in our previous work [11] and the abundance levels are remarkably high in this area. Thusly, this extended work conveys the ubiquity of microplastics in the upper trophic level in order to understand the translocation, which could further be found in human body.

Therefore, the main goal of this study is to evaluate the abundance levels of microplastics ingested by estuarine fish with different life habits (wild and cage-cultured). Physical and chemical characterisations were carried out to identify the main shape and colour of microplastics, polymer composition, and their relationship towards spatial variation.

\section{Sample collection}

\section{Materials and Methods}

Cage-cultured and wild L. calcarifer $(\mathrm{n}=4)$ were caught from Setiu Wetlands in October 2016. Each location was coordinated and illustrated as shown in Table 1 and Figure 1, respectively. Wild L. calcarifer was collected using a drift net (100 m length $\times 2 \mathrm{~m}$ width) located at Stations 3 and 4, where the net was left overnight. Meanwhile, cagecultured $L$. calcarifer was purchased from a local fisherman at the aquaculture site. The weight of each sample was 
set in the range of $300-400 \mathrm{~g}$ regardless of their habitual area. The samples were kept in a cool box filled with ice cubes before the samples were transferred to the laboratory for further analysis.

Table 1. The coordinate of sampling location in Setiu Wetlands

\begin{tabular}{lll}
\hline Station & Latitude (N) & Longitude (E) \\
\hline 1 (Cage Cultured) & $05^{\circ} 37^{\prime} 10.34$ & $102^{\circ} 47^{\prime} 31.51$ \\
2 (Cage Cultured) & $05^{\circ} 39^{\prime} 03.80$ & $102^{\circ} 44^{\prime} 55.32$ \\
3 (Wild) & $05^{\circ} 41^{\prime} 30.77$ & $102^{\circ} 41^{\prime} 54.98$ \\
4 (Wild) & $05^{\circ} 43^{\prime} 21.08$ & $102^{\circ} 47^{\prime} 31.51$ \\
\hline
\end{tabular}

\section{Sample preparation}

In the laboratory, the fish samples were thawed at room temperature and general biological parameters such as length $(\mathrm{cm})$ and weight $(\mathrm{g})$ were measured. The gastrointestinal tract for each sample was removed by dissection as described in previous works reported by Lusher et al. [6] and Rocha-Santos and Duarte [13]. In general, each sample was cut from the top of the oesophagus through the end of the gastrointestinal tract, which was then digested and stored individually in a $250-\mathrm{mL}$ glass jar containing $80 \%$ ethanol solution until further identification. Plastic materials were not used throughout this study as it would cause cross contamination and generate bias in the final result.

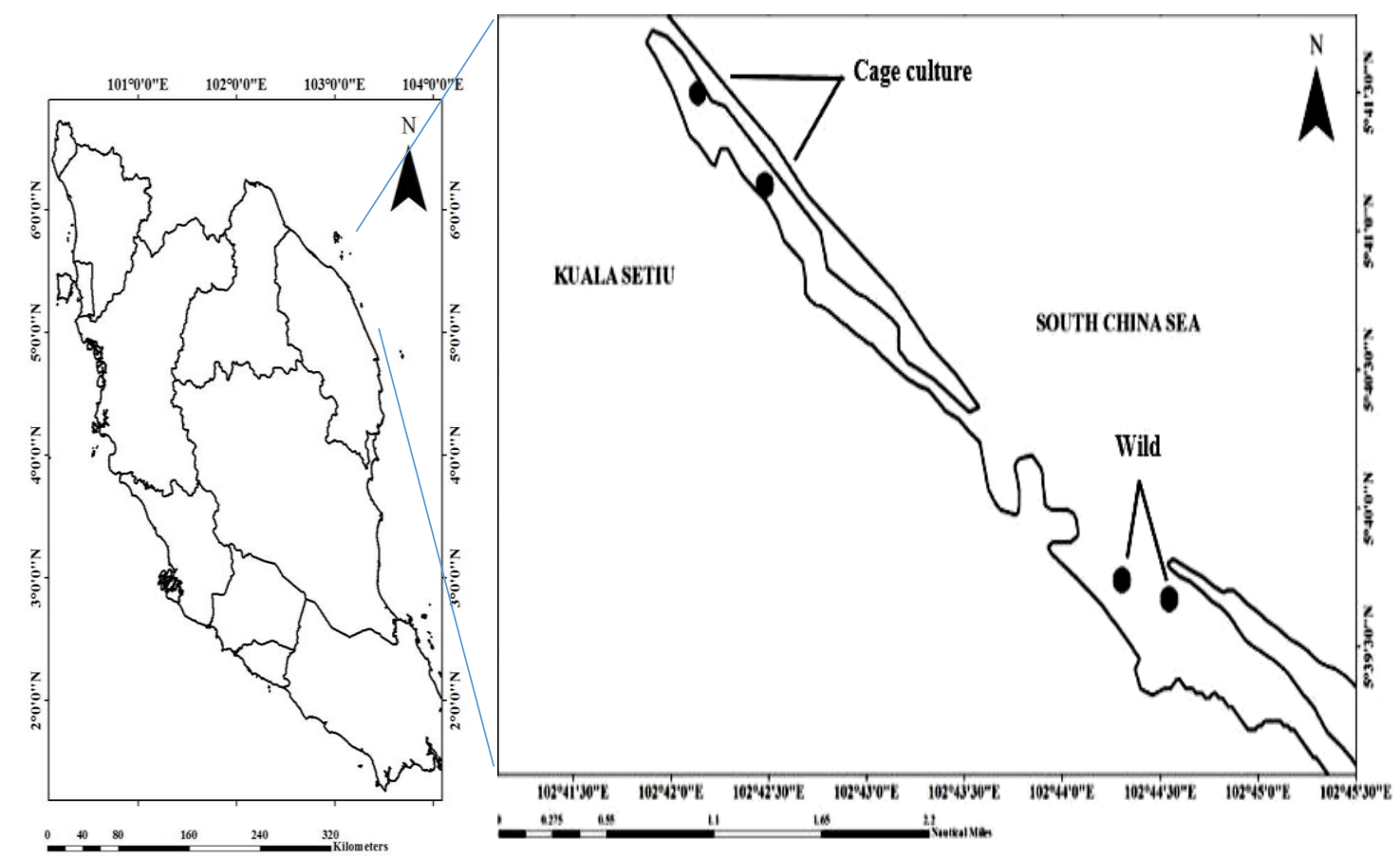

Figure 1. Location of sampling activity in Setiu Wetlands (on left side is map of Peninsular Malaysia) 


\section{Digestion procedure}

The samples were digested using the alkaline method as described by Cole et al. [14] in their work. An amount of $10 \mathrm{M}$ of sodium hydroxide $(\mathrm{NaOH})$ was chosen as the digestion solution and introduced into the beaker containing the gastrointestinal tract. Later, the 50-60 g digested samples were placed in a water bath with the temperature set at $60{ }^{\circ} \mathrm{C}$ and shaken constantly $(130 \mathrm{rpm})$ during the incubation period in order to speed up the digestion process. The digestion steps were carried out in triplicate. After 21 days, the digestion solution was filtered and analysed using a stereoscopic microscope (Leica ZOOM 2000, Cole-Palmer, IL, USA) to observe the presence of microplastic materials.

\section{Microplastic sorting and identification}

The sorted microplastics were photographed and the maximum length, colour, and shape (threadlike, fragment or spherical) were noted using a dissecting microscope (Olympus SZX7, Olympus Corp. Tokyo, Japan). Particles which presented the characteristic features of synthetic polymers were identified as microplastics (mouldable items with consistent thickness and colour which do not break when pressed with stainless forceps). In case of doubt, a hot metal tip was applied on the object. The collected microplastics were kept in individual glass urine bottles pertaining to its original shape. Centrifugation process was carried out to enhance the separation of the microplastic particles from the supernatant before further analysis.

Fourier transform infrared spectroscopy (FTIR) (IR Tracer-100, Perkin Elmer, MA, USA) was used to identify the functional groups associated with polymer chemical properties. Microplastic particles were analysed using attenuated total reflection (ATR) in the mid-IR range of $4000-650 \mathrm{~cm}^{-1}$ and 18 scans per analysis. One-way ANOVA was performed to evaluate the significant level of microplastic abundance among location and shape types. Differences at $\mathrm{p}<0.05$ were considered statistically significant. Statistical analyses (one-way ANOVA) and Pearson correlation were conducted using SPSS statistical package Version 23.0.

\section{Microplastic abundance}

\section{Results and Discussion}

The microplastic size collected in this study was recorded between 4.3 and $15.7 \mu \mathrm{m}$ with an average length of 50.1 $\mu \mathrm{m}$. The total number of microplastics found in all samples was 4,498. The highest abundance of microplastics was found in the gastrointestinal tract of wild L. calcarifer containing 1,260 and 1,277 of digested and microplastic particles, respectively. Meanwhile, the lowest level of ingestion was recorded in cage-cultured fish samples, with a total of 1,961 microplastic fragments in both samples. The microplastic abundance observed between wild and cage-cultured $L$. calcarifer was statistically significant at $p<0.05$. Most of the microplastics found had threadlike shape with distinctive colours (i.e. black, blue, red, green, purple, orange or colourless).

Figure 2 and Figure 3 show the shape and colour distribution of the microplastic particles isolated from the gastrointestinal tracts of $L$. calcarifer during this study, respectively. Black threadlike shape was the most abundant microplastic particle found in both cage-cultured and wild L. calcarifer at different sampling locations, followed by transparent and blue threadlike shapes. The image of microplastic captured under dissecting microscope is presented in Figure 4. Statistical analysis also elucidated that the microplastic abundance based on the colour observed was significantly different between sample type and station at $\mathrm{p}<0.05$. 


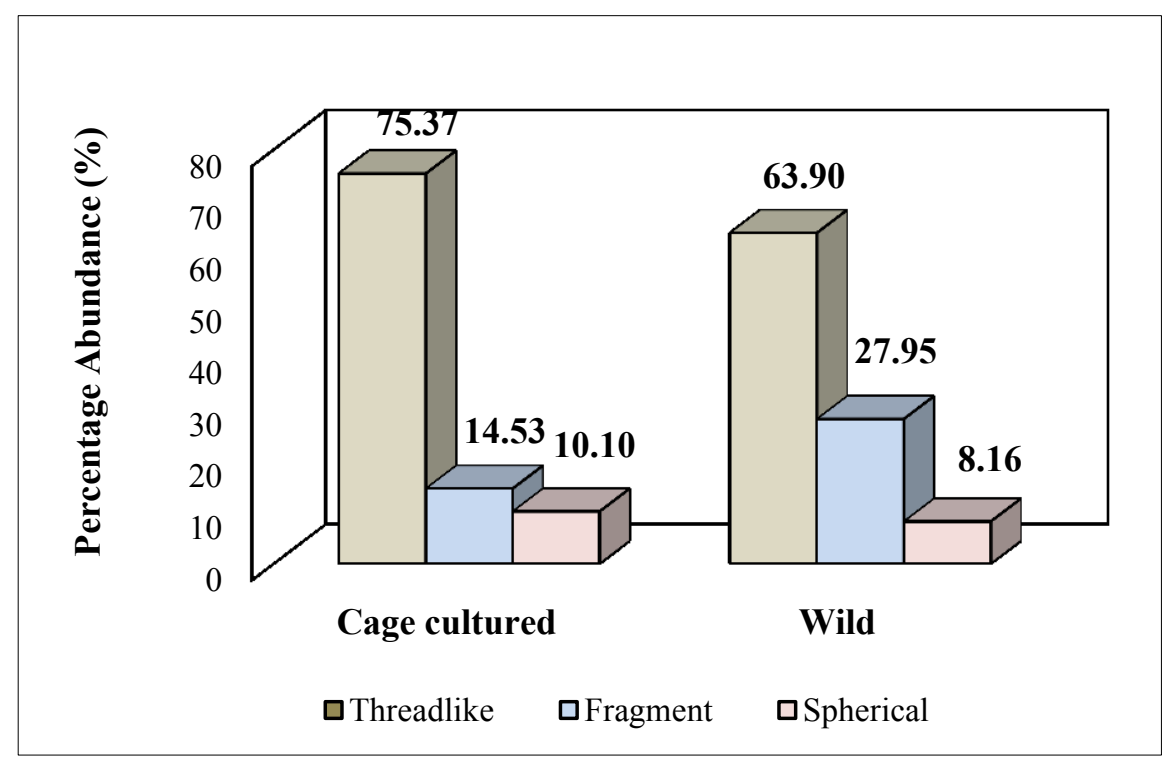

Figure 2. Percentage abundance (\%) of microplastic based on shapes between cage cultured and wild L. calcarifer from Setiu Wetlands

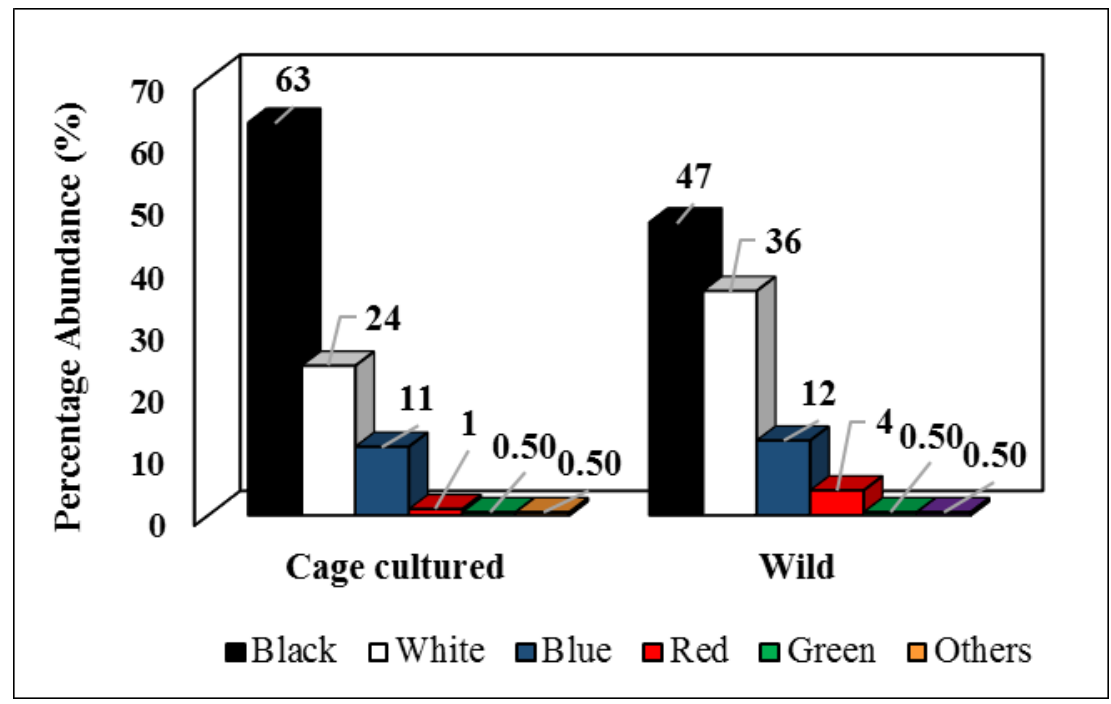

Figure 3. Percentage abundance (\%) of microplastic based on colours between cage cultured and wild L. calcarifer from Setiu Wetlands 

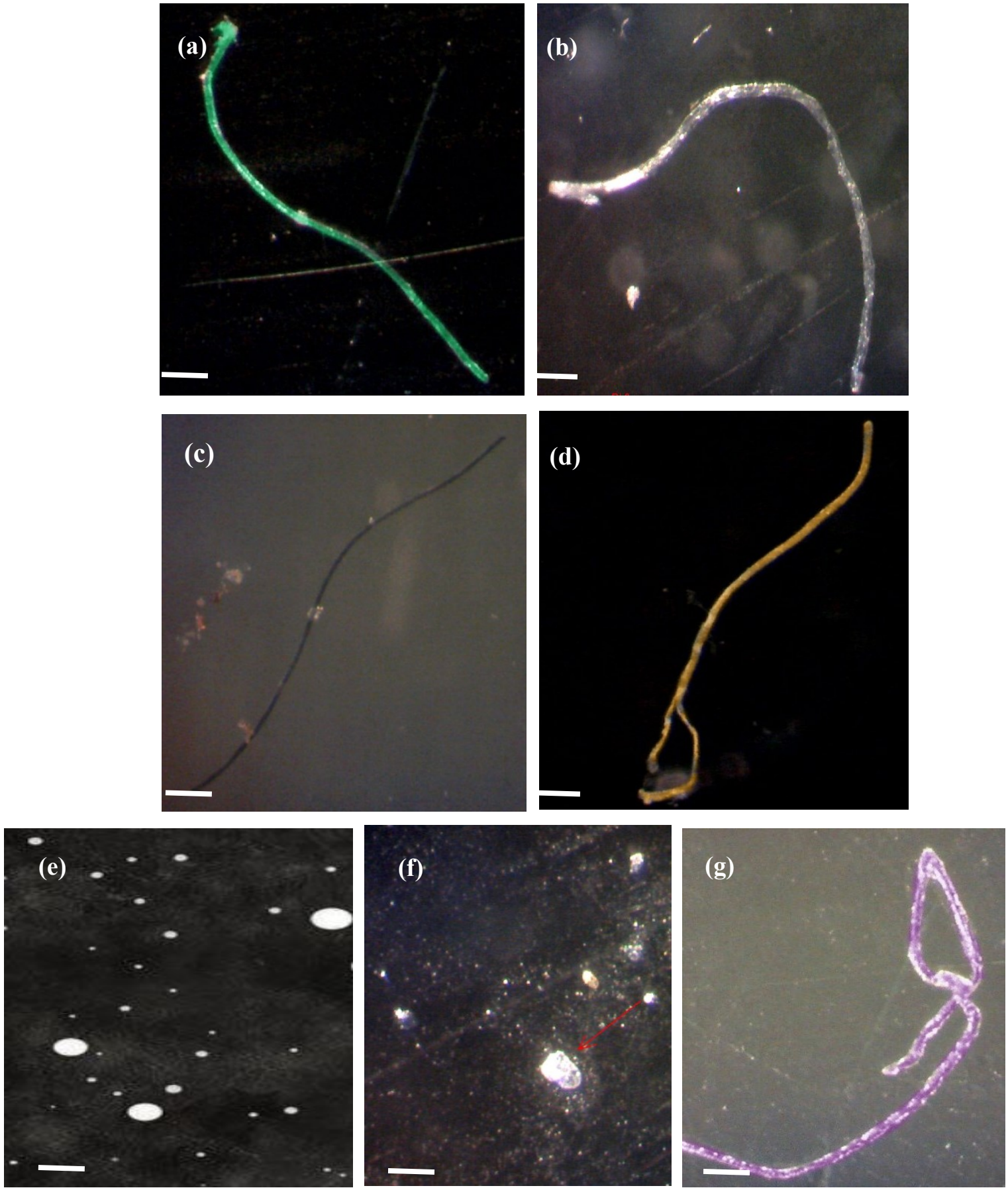

Figure 4. The shapes and colours of microplastic found in cage cultured and wild L. calcarifer a) green threadlike b) transparent threadlike, c) black threadlike, d) orange threadlike, e) white spherical, f) white fragment, and g) purple threadlike. Scale bars: $0.1 \mathrm{~mm}$ 


\section{Characterisation of microplastics}

The FTIR spectra associated to microplastics are shown in Figure 5 and Figure 6 . The collected microplastic particles identified by FTIR spectroscopy analysis proposed that the microplastics found in both wild and cagecultured L. calcarifer were mostly polyamide (PA) (Figure 5) and polyvinyl alcohol (PVA) (Figure 6). In Figure 5, the functional group associated towards microplastic composition shows a strong peak at $3342 \mathrm{~cm}^{-1}$ for $\mathrm{N}-\mathrm{H}$ stretching vibrations from the terminal amine group. Additionally, the $\mathrm{N}-\mathrm{H}$ bending shows the vibration at $v=1510$ $\mathrm{cm}^{-1}$. The absorption band at $v=2852 \mathrm{~cm}^{-1}$ may be attributed to $\mathrm{C}-\mathrm{H}$ aliphatic stretching modes, with the band at $v=1428 \mathrm{~cm}^{-1}$ matches with the bending of $\mathrm{C}-\mathrm{H}_{2}$ vibrations, showing the existence of alkyl chains in the collected microplastics. These findings are in agreement with the previous works reported by Charles et al. [15] and Pavia et al. [16] to elucidate the composition of nylon (polyamide). The band at $v=1706 \mathrm{~cm}^{-1}$ corresponds to the $\mathrm{C}=\mathrm{O}$ carbonyl stretching group vibration, which implies a small part of swaying vibration in the microplastic sample obtained.

The FTIR spectra of PVA carrying all major peaks related to hydroxyl and acetate groups were observed during this study (Figure 6), and similar to the pure PVA spectra recorded by Mansur et al. [17] and Nicodom [18] in their research. The bands observed at $v=3321-3423 \mathrm{~cm}^{-1}$ are linked to the stretching of $\mathrm{O}-\mathrm{H}$ from the intermolecular and intramolecular hydrogen bonds, which is suggested due to the high hydrophilic forces among PVA polymeric chains [19]. The vibrational band observed at $v=2840-3000 \mathrm{~cm}^{-1}$ refers to the stretching of $\mathrm{C}-\mathrm{H}$ from alkyl groups. Moreover, the arrangement of carbonyl, $\mathrm{C}=\mathrm{O}$, which can be distributed randomly along the alkyl chain demonstrated by the bands showed around $v=1706 \mathrm{~cm}^{-1}$, is due to the stretching of $\mathrm{C}=\mathrm{O}$ from the acetate group remaining from PVA [20]. This overlaps with the $\mathrm{O}-\mathrm{H}$ bending peak [17]. The peaks between $v=1174$ and $1219 \mathrm{~cm}^{-}$ ${ }^{1}$ show the $\mathrm{C}-\mathrm{H}_{2}$ wagging and $\mathrm{C}-\mathrm{O}$ carboxyl stretching at $\mathrm{v}=1028-1128 \mathrm{~cm}^{-1}$ vibration absorptions. Thus, it indicates the amorphous and crystalline nature of PVA [17, 20]. PVA is usually amorphous, albeit can be found as a semicrystalline structure for some products. Therefore, this band has been used previously as an indicator for PVA structure as semicrystalline synthetic polymer $[17,21]$.

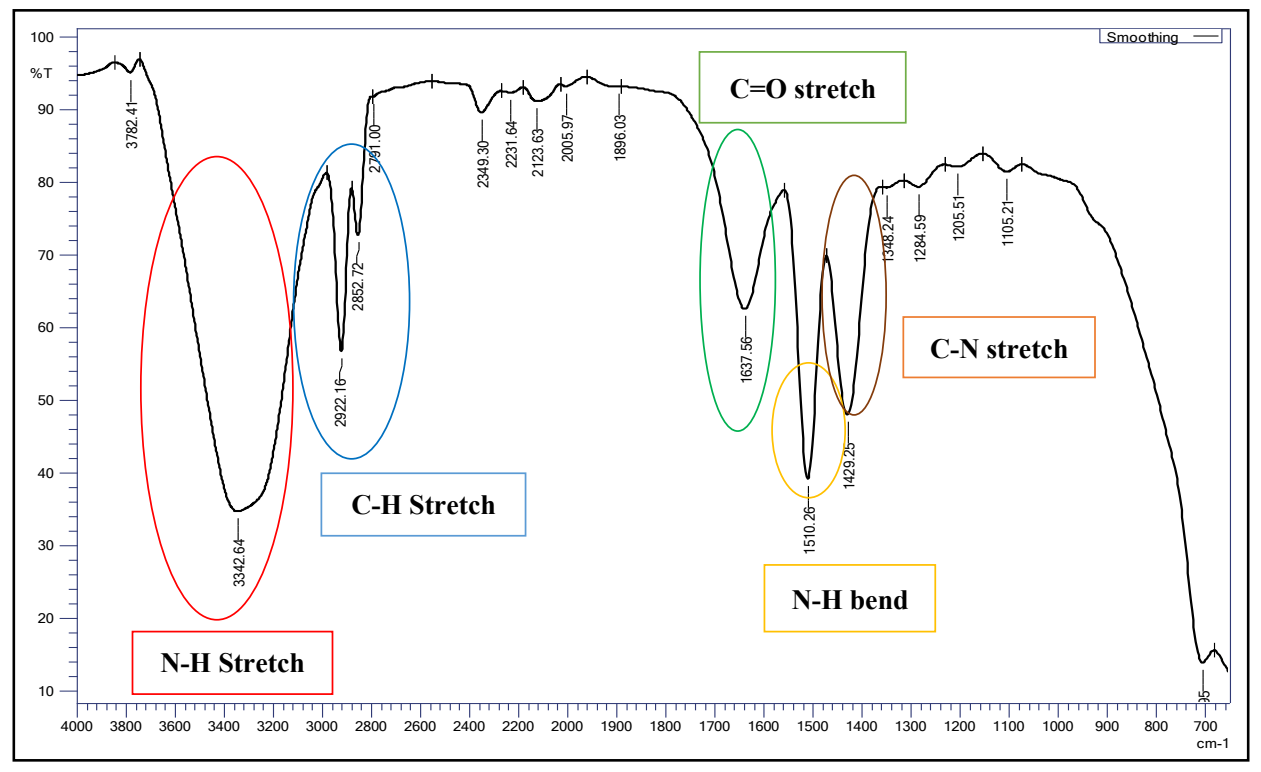

Figure 5. FT-IR spectrum showing the functional group associated to polyamide composition 


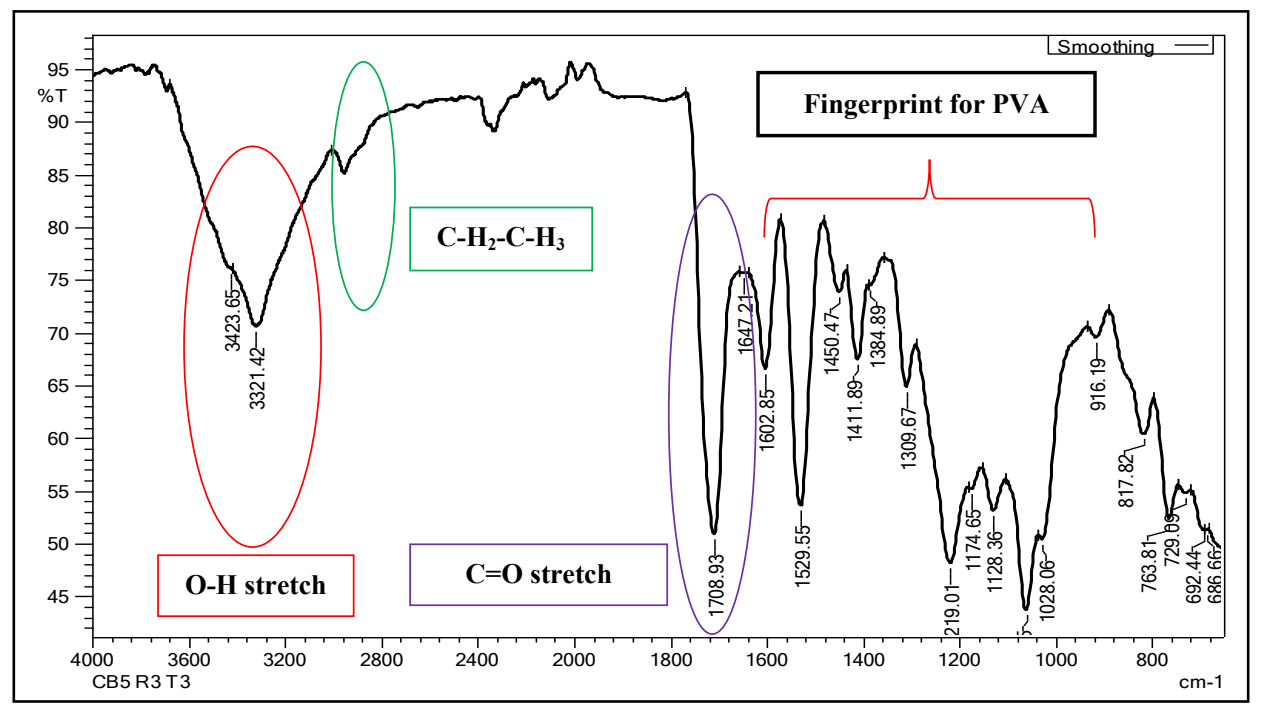

Figure 6. FT-IR spectrum showing the functional group associated to polyvinyl alcohol composition

\section{Spatial variation}

In this study, wild fish showed significantly higher abundance of microplastics than cage-cultured fish $(p<0.05)$. Microplastic ingestion is closely related to different feeding strategies [22, 23, 24]. Brandao et al. [25] suggested that fouling and high density plastics are examples of items that can be ingested by fish through feeding habitat. In this case, this ingestion is probably linked to the normal feeding activity of the fish. Wild fishes of L. calcarifer are known to feed on various preys emerging from different locations and environment as they drift all over the estuary. In contrast, cultured fishes are known to have feeding activities limited to their aquaculture area.

Feeding habitat also plays an important role in the ingestion of debris and lead to the increase of the abundance or bioavailability of microplastics. Higher abundance may be related to different habitats of fishes, and the presence of plastic debris near the seabed is normally high [26]. Referring to Figure 1, the sampling locations of wild and cagecultured L. calcarifer are far from each other. Cage-cultured fishes were collected northwards from Setiu Wetlands, adjacent to the settlement area. Meanwhile, wild fishes were caught nearer to the passage of South China Sea, where several fishermen boats and ships commute in and out of the wetland. The area sampled for wild species has a possibility of higher microplastic particle content in water column as it could be transported from the sea via ocean current and wind. Distinctive habitat also contributes to the difference in microplastic ingestion of the fishes.

The highest microplastic recorded in the gastrointestinal tract of both wild and cage-cultured species is threadlike form; however, the colour coated or additives do not really determine the types of microplastics [27]. Besides the likely contribution from fisheries to the billions of synthetic fibres in the water column, fibres are common in the aquatic environments to which they are delivered in large concentration via wastewater outflow. Browne et al. [28] suggested that the possible sources of fibres in the marine environment are related to the discharge from the sewage sludge or fishing industry, which makes it as the main factor contributing to the emerging microplastics. In fact, cage-cultured fishes ingested more threadlike particles compared to wild species of $L$. calcarifer, probably resulting from the disintegration of nets used in the aquaculture ponds. In contrast, the fragment type was reported remarkably higher in quantity for wild fishes, as it could be denser than water, expected to sink and therefore being accidentally ingested by wild $L$. calcarifer. Pearson correlation also exhibits strong relationship between threadlike and fragment $(\mathrm{r}=0.90)$ but weak towards spherical shape $(\mathrm{r}=0.18)$.

The main polymers found are PA and PVA, where both polymers are slightly denser than water. The standard type of cage used for fish aquaculture, which is made up of synthetic materials, explains the higher number of PA existed in the gastrointestinal tract of cage-cultured species. PA is one of the major materials used to manufacture the nets. In addition, the chances of natural food supply in cages are much less; hence a regular stock of food is necessary. 
The foods are usually composed of raw materials of animals such as small fish heads and inner organs. Thus, there is a higher possibility for the presence of microplastics in cage-cultured species, which is caused by the foods fed. Higher PVA inhabits wild species due to its property that is denser than water and disintegrated fragments from the settlement of abandoned fishing gears and nets on the bottom floor. Furthermore, the existence of human settlements is believed to have contributed to the large volume of microplastic waste, particularly from domestic activities.

\section{Comparison with literature studies}

Since this study is considered as the first report for estuary fishes, the occurrence of polymer type was compared with previously documented literature. A study carried out in the Norwegian coast explicates that the polyester materials become the major fraction of microplastics observed in fish gut samples [29]. Microplastic abundance high in this area is closely linked to high density of population and anthropogenic activities (Bergen City Harbour). Polyester materials were believed to be derived from polypropylene rope, synthetic clothing, and other polyester products. Moreover, it accounted for $88 \%$ of the microplastics found in full stomach samples, which leads to the understanding that the materials are retained longer in the fish body similar to their foods. The comparison of the main polymers found in fish samples is tabulated in Table 2 .

In Durban Harbour, $72.8 \%$ of the microplastics were observed in mullet samples. Polystyrene is one of the polymer subjects found in this study, but it only contributed $7.3 \%$ of the total plastics [30]. The most abundant is in fibre form with white colour. It is worth to note that the correlation between plastic ingestion and fish length or size is not significantly different. The source of pollution especially the emergence of fibres is believed to have originated from domestic or industrial discharge nearby. Meanwhile, recent studies reported by Pazos et al. [31] and Güven et al. [32] indicated that the emergence of a new contaminant affects the multispecies of fishes collected in estuary and coastal areas, respectively. Fibres become the prevalent type of microplastics found in both areas.

Table 2. Comparison of polymer type found in microplastics debris in this study and literature

\begin{tabular}{llll}
\hline Species & Study area & Polymer Identifed & Reference \\
\hline Gadus morhua & Norwegian coast, Norway & Polyester & {$[29]$} \\
Mugil cephalus & Durban Harbour, South Africa & Polystyrene & {$[30]$} \\
Multi species $^{\mathrm{a}}$ & Rio de la Plata estuary, Brazil & - & {$[31]$} \\
Multi species $^{\mathrm{b}}$ & Mediterranean coast, Turkey & Polypropylene, Polyethylene, Polyester & {$[32]$} \\
Lates calcarifer & Setiu Wetland, Malaysia & Polyamide and Polyvinyl alcohol & This study \\
\hline
\end{tabular}

${ }^{\mathrm{a}} 11$ species fish, ${ }^{\mathrm{b}} 28$ species fish

\section{Conclusion}

In this present study, microplastic ingestion has been reported to be pervasive in the gastrointestinal tract of both wild and cage-cultured species of $L$. calcarifer from Setiu Wetlands, Terengganu. The abundance of microplastics is higher in wild species compared to cage-cultured species, which is linked to the dynamics of habitat and feeding activity. PA and PVA are the main polymer compositions found in the gastrointestinal tract of the fishes examined. To the best of our knowledge, the result reported in this study is the first evidence of estuarine fish contaminated by microplastics. Therefore, we highly recommend that in future work, the whole gastrointestinal tract and digestion process should be used in the investigation of microplastic pollution in fish and also not limited to Asian sea bass species only.

\section{Acknowledgement}

The authors are thankful to the Ministry of Higher Education (MOHE) and Universiti Malaysia Terengganu for the financial research grant FRGS 59457. The authors would also like to extend the gratitude to Prof. Dr. Norhayati Mohd. Tahir, Assoc. Prof. Dr. Siti Aishah Abdullah (School of Marine and Environmental Sciences) and Dr. 
Shumpei Iehata (School of Fisheries and Aquaculture Sciences) for their valuable assistance and guideline while conducting this research.

\section{References}

1. Browne, M. A., Underwood, A. J., Chapman, M. G., Williams, R., Thompson, R. C. and van Franeker, J. A. (2015). Linking effect of anthropogenic debris to ecological impacts. Proceedings of the Royal Society B: Biological Sciences, 28: 2014 - 2929.

2. Browne, M. A., Dissanayake, A., Galloway, T. S., Lowe, D. M. and Thompson, R. C. (2008). Ingested microscopic plastic translocates to the circulatory system of the mussel, Mytilus edulis (L.). Environmental Science \& Technology, 42: 5026 - 5031.

3. Ivor Do Sul, J. A., Costa, M. F., Barletta, M. and Cysneiros, F.J. (2013). Pelagic microplastics around an archipelago of the Equatorial Atlantic. Marine Pollution Bulletin, 75: 305 - 307.

4. Boerger, C. M., Lattin, G. L., Moore, S. L. and Moore, C. J. (2010). Plastic ingestion by planktivorous fishes in the North Pacific Central Gyre. Marine Pollution Bulletin, 60(12): 2275 - 2278.

5. Possatto, F. E., Barletta, M., Costa, M. F., do Sul, J. A. I. and Dantas, D. V. (2011). Plastic debris ingestion by marine catfish: An unexpected fisheries impact. Marine Pollution Bulletin, 62(5): 1098 -1102.

6. Lusher, A. L., McHugh, M. and Thompson, R. C. (2013). Occurrence of microplastics in gastrointestinal tract of pelagic and demersal fish from the English Channel. Marine Pollution Bulletin, 67: 94 - 99.

7. Foekema, E. M., De Gruijter, C., Mergia, M. T., van Franeker, J. A., Murk, A. J. and Koelmans, A. A. (2013). Plastic in north sea fish. Environmental Science \& Technology, 47(15): 8818 - 8824.

8. Rummel, C. D., Löder, M. G., Fricke, N. F., Lang, T., Griebeler, E. M., Janke, M. and Gerdts, G. (2016). Plastic ingestion by pelagic and demersal fish from the North Sea and Baltic Sea. Marine Pollution Bulletin, 102(1): $134-141$.

9. Barasarathi, J., Agamuthu, P., Emenike, C. U. and Fauziah, S. H. (2014). Microplastic abundance in selected mangrove forest in Malaysia. In Proceeding of the ASEAN Conference on Science and Technology, pp. $1-5$.

10. Noik, V. J. and Tuah, P. M. (2015). A first survey on the abundance of plastics fragments and particles on two sandy beaches in Kuching, Sarawak, Malaysia. In IOP Conference Series: Materials Science and Engineering, 78(1): 012035.

11. Ibrahim, Y. S. (2016). Microplastics ingestion by Scapharca cornea at Setiu Wetland, Terengganu, Malaysia. Middle-East Journal of Scientific Research, 24: 2129 - 2136.

12. Amin, N. M. and Hasan, F. A. (Eds.). (2003). Setiu Wetlands: Tranquility amidst plenty, $1^{\text {st }}$ Ed. Kolej Universiti Sains dan Teknologi Malaysia: Kuala Terengganu, Malaysia.

13. Rocha-Santos, T. and Duarte, A. C. (2015). A critical overview of the analytical approaches to the occurrence, the fate and the behavior of microplastics in the environment. TrAC Trends in Analytical Chemistry, 65: $47-$ 53.

14. Cole, M., Webb, H., Lindeque, P. K., Fileman, E. S., Halsband, C. and Galloway, T. S. (2014). Isolation of microplastics in biota-rich seawater samples and marine organisms. Scientific Reports, 4: 4528.

15. Charles, J., Ramkumaar, G. R., Azhagiri, S. and Gunasekaran, S. (2009). FTIR and thermal studies on nylon-66 and 30\% glass fibre reinforced nylon-66. Journal of Chemistry, 6:23-33.

16. Pavia D. L., Lampman G. M., Kriz G. S. and Vyvyan J. R. (2008). Infrared Spectroscopy, In: Introduction to Spectroscopy. Brooks/Cole: CA, USA.

17. Mansur, H. S., Sadahira, C. M., Souza, A. N. and Mansur, A. A. (2008). FTIR spectroscopy characterization of poly(vinyl alcohol) hydrogel with different hydrolysis degree and chemically crosslinked with glutaraldehyde. Materials Science and Engineering: C, 28: $539-548$.

18. Nicodom Ltd (2007). Nicodom libraries: poly vinyl alcohol. Retrieved from http://www.ftir-polymers.com. [Access date: $21^{\text {st }}$ March 2017].

19. Hassan, C. M. and Peppas N. A. (2000). Structure and applications of poly (vinyl alcohol) hydrogels produced by conventional crosslinking or by freezing/thawing methods. Advance Polymer Science, 153: 37 - 65.

20. Mansur H. S. Orélice R. L. and Mansur A. A. P (2004). Characterization of poly (vinyl alcohol)/poly(ethylene glycol) hydrogels and PVA-derived hybrids by small-angle X-ray scattering and FTIR spectroscopy. Polymers, 45: $7193-7202$.

21. Hennink W. E. and Nostrum C. F. (2002) Novel crosslinking methods to design hydrogels. Advance Drug Delivery Reviews, 17: 13 - 36. 
22. Anastasopoulou, A., Mytilineou, C., Smith, C. J. and Papadopoulou, K. N. (2013). Plastic debris ingested by deep-water fish of the Ionian Sea (Eastern Mediterranean). Deep Sea Research Part I: Oceanographic Research Papers, 74: $11-13$.

23. Battaglia, P., Pedà, C., Musolino, S., Esposito, V., Andaloro, F. and Romeo, T. (2016). Diet and first documented data on plastic ingestion of Trachinotus ovatus L. 1758 (Pisces: Carangidae) from the Strait of Messina (central Mediterranean Sea). Italian Journal of Zoology, 83: 121 - 129.

24. Romeo, T., Pietro, B., Pedà, C., Consoli, P., Andaloro, F. and Fossi, M. C. (2015). First evidence of presence of plastic debris in stomach of large pelagic fish in the Mediterranean Sea. Marine Pollution Bulletin, 95: 358 361.

25. Brandão, M. L., Braga, K. M. and Luque, J. L. (2011). Marine debris ingestion by Magellanic penguins, Spheniscus magellanicus (Aves: Sphenisciformes), from the Brazilian coastal zone. Marine Pollution Bulletin, 62: $2246-2249$.

26. Woodall, L. C., Sanchez-Vidal, A., Canals, M., Paterson, G. L., Coppock, R., Sleight, V. and Thompson, R. C. (2014). The deep sea is a major sink for microplastic debris. Royal Society Open Science, 1: 140 - 317.

27. Andrady, A. L. (2011). Microplastic in the marine environment. Marine Pollution Bulletin, 62: 1596-1605.

28. Browne, M. A., Crump, P., Niven, S. J., Teuten, E., Tonkin, A., Galloway, T. and Thompson, R. (2011). Accumulation of microplastic on shorelines worldwide: sources and sinks. Environmental Science \& Technology, 45(21): $9175-9179$.

29. Bråte, I. L. N., Eidsvoll, D. P., Steindal, C. C. and Thomas, K. V. (2016). Plastic ingestion by Atlantic cod (Gadus morhua) from the Norwegian coast. Marine Pollution Bulletin, 112(1): 105 - 110.

30. Naidoo, T., Smit, A. J. and Glassom, D. (2016). Plastic ingestion by estuarine mullet Mugil cephalus (Mugilidae) in an urban harbour, KwaZulu-Natal, South Africa. African Journal of Marine Science, 38(1): 145 $-149$.

31. Pazos, R. S., Maiztegui, T., Colautti, D. C., Paracampo, A. H. and Gómez, N. (2017). Microplastics in gut contents of coastal freshwater fish from Río de la Plata estuary. Marine Pollution Bulletin, 122 (1-2): 85 - 90.

32. Güven, O., Gökdağ, K., Jovanović, B. and Kıdeyş, A. E. (2017). Microplastic litter composition of the Turkish territorial waters of the Mediterranean Sea, and its occurrence in the gastrointestinal tract of fish. Environmental Pollution, 223: 286 - 294. 